\title{
PENGARUH KUALITAS PELAYANAN DAN KENYAMANAAN TERHADAP KEPUASAN KONSUMEN PADA PERUSAHAAN JASA OJEK ONLINE GO-JEK DI KOTA KEDIRI
}

\author{
Dhita Tresiya; Djunaidi; Heri Subagyo \\ Fakultas Ekonomi - Universitas Kadiri \\ E-mail : djunaidi@unik-kediri.ac.id
}

\begin{abstract}
The objectives of this study are: (1) To determine the effect of service quality on consumer satisfaction of Go-jek online motorcycle taxi users in the City of Kediri. (2) To determine the effect of comfort on consumer satisfaction on Go-jek online motorcycle taxi users in Kediri City. (3) To determine the effect of service quality and comfort on customer satisfaction Go-jek motorcycle taxi users in Kediri City. The population in this study were all consumers using Go-Jek online motorcycle taxi services in Kediri City. The sampling technique used snowball sampling with a total sample of 100 people. The data collection technique uses a questionnaire that has been tested for validity and reliability. The analysis technique used is multiple regression analysis. The results showed that: (1) Service quality did not affect consumer satisfaction Go-Jek motorcycle taxi users in Kota Kediri (2) Convenience had a significant effect on customer satisfaction Go-Jek motorcycle taxi users in the city (3) Service quality and Comfort significant effect on consumer satisfaction Go-Jek online motorcycle taxi users in the City of Kediri.
\end{abstract}

Keywords: Service Quality, Comfort, Consumer Satisfaction

\begin{abstract}
ABSTRAK
Tujuan dari penelitian ini ialah : (1) Untuk mengetahui pengaruh kualitas pelayanan terhadap kepuasan konsumen pengguna ojek online Go-jek di Kota Kediri. (2) Untuk mengetahui pengaruh kenyamanan terhadap kepuasan konsumen pengguna jasa ojek online Go-jek di Kota Kediri. (3) Untuk mengetahui pengaruh kualitas pelayanan dan kenyamanan terhadap kepuasan konsumen pengguna jasa ojek online Go-jek di Kota Kediri. Populasi pada penelitian ini adalah seluruh konsumen pengguna jasa ojek online Go-Jek di Kota Kediri. Teknik pengambilan sampel menggunakan snowball sampling dengan jumlah sampel sebanyak 100 orang. Teknik pengambilan data menggunakan kuesioner yang telah diuji validitas dan reliabilitasnya. Teknik analisis yang digunakan adalah analisis regresi berganda. Hasil penelitian menunjukkan bahwa: (1) Kualitas pelayanan tidak berpengaruh terhadap kepuasan konsumen pengguna jasa ojek online Go-Jek di Kota Kediri (2) Kenyamanan berpengaruh signifikan terhadap kepuasan konsumen pengguna jasa ojek online Go-Jek di Kota (3) Kualitas pelayanan dan Kenyamanan berpengaruh signifikan terhadap kepuasan konsumen pengguna jasa ojek online Go-Jek di Kota Kediri.
\end{abstract}

Kata kunci: Kualitas Pelayanan, Kenyamanan, Kepuasan Konsumen 


\section{PENDAHULUAN}

Seiring dengan berkembangnya zaman yang sangat pesat pada era milenial ini populasi dan mobilitas manusia mengalami peningkatan yang sangat signifikan pada setiap tahun. Akibat dari perkembangan zaman tersebut kondisi kota menjadi semakin padat oleh segala aktifitas warganya dan salah satu akibat yang ditimbulkan adalah meningkanya penggunaan sarana transportasi di kota-kota besar, termasuk juga seperti di kota Kediri. Kemajuan pada bidang teknologi informasi yang sangat pesat memberikan pengaruh yang besar terhadap berbagai aspek kehidupan manusia.

Saat ini bisa kita lihat banyak bermunculan layanan-layanan jasa yang berbasis online yang bisa menjangkau langsung pada konsumen, mempermudah segala aktifitas dan kehidupan sehari-hari. Dari beberapa layanan jasa online tersebut ada suatu ide yang membuat layanan jasa transportasi online, kehadiran jasa transportasi berbasis online yang menggunakan internet sebagai media sangat berpengaruh bagi masyarakat dalam segala aktifitas dan kelangsungan hidup, dengan adanya jasa transportasi online sangat membantu untuk mempersingkat waktu agar lebih efisien. Akan tetapi munculnya jasa transportasi online juga menimbulkan berbagai masalah, contohnya adalah perselisihan antara pengemudi transportasi online dan juga pengemudi transportasi konvensional.

Dengan banyaknya bermunculan jasa transportasi online ini mengakibatkan semakin kuatnya persaingan yang dihadapi oleh para pengemudi transportasi konvensional. Hampir disetiap sudut kota dan area pusat keramaian seperti kawasan sekolah, kawasan perbelanjaan, rumah sakit dan kawasan perkantoran banyak ditemui para pengemudi transportasi online (Gandung Satriyono \& Desi Kristanti, 2018). Selain masalah itu apabila kita cermati ada beberapa hal yang harus dibenahi dan dibuat suatu peraturan pada layanan transportasi yang ada saat ini khususnya masalah keselamatan, kesopanan, dan kenyamanan serta ambang batas tarif normal dari layanan transportasi tersebut.

Kini telah muncul ide baru perusahaan taxi motor atau bisnis jasa transportasi yang berbasis online dengan mengunakan media internet yang menawarkan berbagai kenyamanan dan hal baru yang yang berbeda serta tidak bisa dilakukan oleh jasa transportasi pada umumnya. Ojek yang bisa diakses melalui smartphone kita dimanapun dan kapanpun. 
Cara kerja Go-Jek terbilang sangat simpel, efektif dan efisien secara waktu. Hanya menggunakan aplikasi playstore yang ada pada smartphone yang telah terhubung dengan koneksi internet. Para pelanggan tidak perlu lagi menunggu dipinggir jalan ataupun berjalan terlebih dahulu untuk mendatangi pangkalan ojek. Cara pemesanan Go-Jek cukup dengan melalui aplikasi Go-Jek yang telah diunduh pada smartphone kemudian pelanggan tinggal pilih layanan yang dibutuhkan. Gojek mau mengantar kapan saja dimana saja selama ada koneksi internet dan wilayah pemesan tidak terlalu jauh dari perkotaan pasti akan terlayani dengan baik, bahkan bukan hanya untuk mengantarkan penumpang tapi juga melayani go food, go send, go tik dan lain sebagainya.

Kualitas pelayanan yang baik menjadi keunggulan dan modal bersaing bagi perusahaan jasa. Kualitas pelayanan juga merupakan kunci untuk mencapai kesuksesan. Baik atau buruknya kualitas pelayanan barang dan jasa tergantung pada kemampuan perusahaan dalam memenuhi kebutuhan dan harapan konsumen. Kualitas pelayanan dikatakan memuaskan apabila layanan yang dirasakan konsumen sama atau melebihi kualitas layanan yang diharapkan oleh konsumen tersebut. Harapan konsumen tercermin pada pelayanan yang baik, ramah tamah, sopan santun ,ketepatan waktu, dan kecepatan menjadi nilai penting yang diharapkan oleh konsumen. Konsumen merasa puas secara tidak langsung akan mendorong terjadinya rekomendasi dari mulut ke mulut. Oleh karena itu, kualitas pelayanan harus menjadi focus utama perusahaan karena dapat menciptakan kepuasan pelanggan (Yunanto, 2017).

Dalam upaya memenuhi kepuasan konsumen terhadap layanan dan hasil kinerja juga akan mempengaruhi kenyamanan yang akan dirasakan konsumen itu sendiri. Semakin baik kenyamanan yang dirasakan konsumen, maka semakin tinggi rasa kepuasannya. Rasa nyaman dan aman merupakan alasan utam untuk seseorang bersikap loyal terhadap suatu pelayanan dan pelanggan bisa loyal terhadap pelayan jasa. Sehingga ini merupakan asset dari perusahaan karena telah mendapat kepercayaan dari konsumen.

Selain itu kepuasan konsumen merupakan faktor utama untuk menilai kualitas pelayanan dari suatu produsen maupun perusahaan, dimana konsumen menilai kinerja dan kualitas pelayanan yang dirasakan langsung oleh konsumen terhadap suatu produk ataupun jasa yang diberikan. Kualitas pelayanan ditentukan oleh bagaimana tingkat 
kesesuaian antara jasa pelayanan yang diberikan oleh penyedia jasa dengan seperti apa yang diharapkan oleh pengguna layanan jasa tersebut. Semakin tinggi kualitas pelayanan yang diberikan maka akan semakin tinggi juga kepuasan yang dirasakan oleh pengguna jasa tersebut.

Gojek telah dipercaya oleh beragam pengguna jasa dalam membantu aktifitas dan memenuhi kebutuhan kelangsungan hidup mereka. Sebagai salah satu perusahaan yang sedang berkembang pesat pada akhir-akhir ini, Gojek sedang gencar untuk meningkatkan pelayanan salah satunya dengan cara memberikan rasa nyaman dan aman yang akan dirasakan oleh konsumen. Tapi apabila kita ceramati lebih lanjut ada banyak hal yang perlu dibenahi dari layanan Go-Jek khususnya pada masalah kualitas pelayanan ternyata Go-Jek tidak menyedikan jas hujan bagi penumpangnya untuk menjamin keselamatan penumpang disaat hujan. Selain hal itu ternyata perusahaan GoJek juga tidak menyediakan masker penutup dan penutup rambut untuk para penumpang. Karena pelayanan yang kurang ini bisa jadi menyebabkan Go-Jek dipandang negative oleh para konsumen dan apabila hal ini dibiarkan terus menerus artinya driver Go-Jek tidak bekerja sesuai dengan standart yang ditetapkan dan tentunya akan menyebabkan konsumen merasa tidak puas.

Berdasarkan uraian latar belakang diatas maka penulis telah menetapkan judul dalam penelitian kali ini, adapun judul dari penelitian kali ini yaitu : “Pengaruh Kualitas Pelayanan Dan Kenyamanaan Terhadap Kepuasan Konsumen (Studi Pada Perusahaan Jasa Ojek Online Go-Jek Di Kota Kediri)”.

\section{Rumusan Masalah}

Untuk memudahkan dalam penelitian ini, Adapun permasalahan yang diangkat peneliti, yaitu :

1. Apakah kualitas pelayanan berpengaruh positif terhadap kepuasan konsumen pengguna jasa ojek online Go-jek di Kota Kediri?

2. Apakah kenyamanan berpengaruh positif terhadap kepuasan konsumen pengguna jasa ojek online Go-jek di kota kediri ?

3. Apakah kualitas pelayanan dan kenyamanan berpengaruh positif tethadap kepuasan konsumen pengguna jasa ojek online Go-jek di kota Kediri ? 


\section{Tujuan Penelitian}

Berdasarkan latar belakang dan rumusan masalah dari penelitian ini, peneliti memiliki tujuan dalam kegiatan penelitian ini, adapun tujuan yang peneliti harapkan dari penelitian ini yaitu :

1. Untuk mengetahui pengaruh kualitas pelayanan terhadap kepuasan konsumen pengguna ojek online Go-jek di Kota Kediri.

2. Untuk mengetahui pengaruh kenyamanan terhadap kepuasan konsumen pengguna jasa ojek online Go-jek di Kota Kediri.

3. Untuk mengetahui pengaruh kualitas pelayanan dan kenyamanan terhadap kepuasan konsumen pengguna jasa ojek online Go-jek di Kota Kediri.

\section{TINJAUAN PUSTAKA}

\section{Penelitian terdahulu}

\section{Tabel 1 : Penelitian Terdahulu}

\begin{tabular}{|c|c|c|c|c|}
\hline NO & $\begin{array}{l}\text { Nama } \\
\text { Peneliti }\end{array}$ & Judul & $\begin{array}{c}\text { Variabel dan Alat } \\
\text { Analisis }\end{array}$ & Hasil Penelitian \\
\hline 1. & $\begin{array}{l}\text { Januar } \\
\text { Efendi } \\
\text { Panjaitan } \\
\text { \& Ai Lili } \\
\text { Yuliati } \\
(2016)\end{array}$ & $\begin{array}{l}\text { Pengaruh } \\
\text { Kualitas } \\
\text { Terhadap } \\
\text { Kepuasan } \\
\text { Pelanggan } \\
\text { pada Cabang } \\
\text { JNE Bandung }\end{array}$ & $\begin{array}{l}\text { Jenis penelitian: } \\
\text { Deskriptif } \\
\text { Variabel : } \\
1 . \quad \text { Kualitas } \\
\text { pelayanan } \\
2 . \quad \text { Kepuasan } \\
\text { pelanggan } \\
\text { Analisis data: } \\
\text { Regresi linier } \\
\text { berganda }\end{array}$ & $\begin{array}{l}\text { Hasil penelitian ini bahwa Kualitas } \\
\text { pelayanan }(\mathrm{X}) \text { yang terdiri dari } \\
\text { kendala, kepastian, kenyataan, } \\
\text { empati, dan daya tanggap, memiliki } \\
\text { pengaruh signifikan terhadap } \\
\text { kepuasan pelanggan dengan nilai } \\
\text { (nilai p) } 0.003<0.05 \text {. sebagai hasil } \\
\text { uji mengajukan bahwa hanya } \\
\text { variabel empati yang memiliki } \\
\text { bagian pengaruh dalam kepuasan } \\
\text { pelanggan dengan jumlah variabel } \\
\text { signifikan (nilai p) berjumlah } 0.021 \\
<0.05 \text {. }\end{array}$ \\
\hline 2. & $\begin{array}{l}\text { Afrinda } \\
\text { Kharista } \\
\text { dkk (2015) }\end{array}$ & $\begin{array}{l}\text { Pengaruh } \\
\text { Kualitas } \\
\text { Pelayanan } \\
\text { Terhadap } \\
\text { Kepuasan } \\
\text { Pelanggan } \\
\text { (survey pada } \\
\text { pelanggan } \\
\text { Fedex } \\
\text { Express } \\
\text { Surabaya) }\end{array}$ & $\begin{array}{l}\text { Jenis penelitian: } \\
\text { Penelitian } \\
\text { eksplanatori } \\
\text { Variabel : } \\
\text { Kualitas pelayanan } \\
\text { Kepuasan } \\
\text { pelanggan } \\
\text { Analisis Data: } \\
\text { Analisi deskriptif } \\
\text { Analisis regresi } \\
\text { linier berganda }\end{array}$ & $\begin{array}{l}\text { Kepuasan pelanggan dipengaruhi } \\
\text { sig secara parsial oleh variabel } \\
\text { kualitas pelayanan yang terdiri dari } \\
\text { variabel Tangible }(x 1) \text {, Reability } \\
(x 2) \text {, Responsiveness }(x 3) \text {, } \\
\text { Assurance }(x 4) \text {, dan Empathy }(x 5) \\
\text { dengan hasil sigt }(0,000)<\alpha 0,005 \text {. } \\
\text { sedangkan variabel Tangible }(\mathrm{X} 1) \\
\text { menunjukkan hasil yang tidak sig } \\
\text { terhadap kepuasan pelanggan } \\
\text { dengan nilai } \mathrm{t}(0,000)>\alpha 0,05 \text {. }\end{array}$ \\
\hline
\end{tabular}




\section{Kualitas Pelayanan}

\section{Pengertian kualitas pelayanan}

"Kualitas pelayanan merupakan suatu kondisi dinamis yang berhubungan dengan produk, jasa, manusia, proses, dan lingkungan yang memenuhi atau melebihi harapan”. Goeth dan Davis yang dikutip (Tjiptono,2012:51).

Proses pemenuhan kebutuhan melalui aktivitas orang lain yang langsung inilah yang dinamakan pelayanan (Moenir 2001:17). Sehingga definisi kualitas pelayanan dapat diartikan sebagai upaya memenuhi kebutuha dan keinginan konsumen serta ketepatan penyampaiannya dalam mengimbangi harapan konsumen (Tjipono,2007).

Dari pengertian dari beberapa para ahli dapat penulis simpulkan bahwa kualitas pelayanan yaitu segala sesuatu yang diharapkan konsumen agar dapat memenuhi kebutuhan yang diinginkan pelanggan sehingga mendapat kepercayaan dari pelanggan.

\section{Prinsip - prinsip dimensi pelayanan}

Menurut Parasuraman, Zeithaml, dan Berry (1985) yang dikutip oleh Fandy Tjiptono (2012:174) menjelaskan bahwa akan menilai kualitas pelayanan melalui lima prinsip dimensi pelayanan sebagai ukurannya, yaitu sebagai berikut: Realibilitas (Realibility), Daya Tanggap (Responsiveness), Jaminan (Assurance), Empati (Empathy) dan bukti Fisik (Tangibles)

\section{Faktor yang Mempengaruhi Kualitas Pelayanan}

Menurut Lupiyoadi dan Hamdani (2008:75) terdapat 4 peranan atau pengaruh dari aspek konsumen yang akan mempengaruhi konsumen lain yaitu:

1. Contractors yaitu calon pelanggan baru sering berinteraksi dengan pelanggan lama yang dapat mendorong keputusan pembelian.

2. Modifier yaitu calon pelanggan baru sering berhubungan dengan konsumen lain dengan berbagai karakter.

3. Influencer yaitu mempengaruhi konsumen secara tidak langsung melalui kontak yang ada.

4. Isolated yaitu calon konsumen ikut serta dalam bauran pemasaran walaupun mereka tidak pernah bertemu dengan konsumen yang lain. 


\section{Kenyamanan Konsumen}

Pengertian kenyamanan

Sander dan McCormik dalam Ardiana (2007) yang menyatakan bahwa kenyamanan adalah suatu kondisi perasaan dan sangat bergantung pada orang yang mengalami situasi tersebut. Kita tidak dapat mengetahui tingkat kenyamanan yang dirasakan orang lain secara langsung dengan observasi, kita harus menanyakan pada orang tersebut untuk memberitahukan pada kita seberapa nyaman diri mereka.

Kolcaba (dalam Potter \& Perry, 2005) mengungkapkan “ kenyamanan atau rasa nyaman adalah suatu keadaan telah terpenuhinya kebutuhan dasar manusia yaitu kebutuhan ketentraman (suatu kepuasan yang meningkatkan penampilan sehari-hari), kelegaan (kebutuhan telah terpenuhi), dan transenden (keadaan tentang suatu yang melebihi masalah)".

Kenyamanan mesti dipandang holistik yang mencangkup empat aspek yaitu:

1. Fisik, merupakan ungkapan rasa yang dirasakan oleh paad tubuh seseorang.

2. Sosial, merupakan bagaimana komunikasi yang dijalin.

3. Psikospiritual, yang terkait dengan rasa yang ada pada diri sesorang meliputi : harga diri, seksualitas, makna kehidupan.

4. Lingkungan, merupakan gambaran lingkungan ksternal dan internal seseorang.

Dari pengertian dari para ahli diatas penulis menyimpulkan bahwa kenyamanan merupakan suatu kondisi perasaan yang tidak dapat kita kengetahui tingkat kenyamana yang dirasakan oleh orang lain secara langsung. Perasaan nyaman atau tidak nyaman sangat bergantung pada masing - masing individu yang mengalami situasi tersebut.

\section{Aspek dalam kenyamanan}

Menurut Karwowski dan Marras (2003) mencoba mengukur kenyamana secara objektif melalui pengukuran ketidaknyamanan dengan melihat 4 aspek yaitu :

1) Intensitas

2) Kualitas

3) Lokasi

4) Periode waktu 


\section{Kepuasan Konsumen}

\section{Pengertian Kepuasan Konsumen}

Menurut Schnaars ( Tjiptono 2002 : 24) “ pada dasarnya tujuan dari suatu bisnis adalah untuk menciptakan pelanggan yang merasa puas. Terciptanya kepuasan pelanggan dapat memberi manfaat diantaranya hubungan antara perusahaan dan pelanggan menjadi harmonis, memberikan dasar yang baik bagi pembeli berulang dan terciptanya loyalitas pelanggan, dan membentuk suatu rekomendasi dari mulu ke mulut ( word of mouth) yang menguntungkan bagi perusahaan".

Menurut Kotler (2001) "kepuasan adalah perasaan senang atau kecewa seseorang yang muncul setelah membandingkan antara persepsi atau kesan terhadap kinerja atau hasil suatu produk dan harapan-harapannya. Jadi, kepuasan merupakan fungsi dari persepsi atau kesan atas kinerja dan harapan. Jika kinerja memenuhi harapanb maka pelanggan akan puas.jika kinerja melebihi harapan maka pelanggan akan amat puas atau senang. Kunci untuk menghasilkan kesetiaan pelanggan adalah memberikan nilai pelanggan yang tinggi “.

Berdasarkan pendapat para ahi penulis menyimpulkan bahwa Kepuasan pelanggan adalah hasil dari kualitas pelayanan yang dirasakan oleh pelanggan apakah produk yang ditawarkan oleh perusahaan sesuai yang diharapkan, jadi saat pelayanan yang disajikan kepada konsumen bagus, maka pelanggan akan merasa puas dan sebaliknya bila pelayanan yang disajikan tidak bagus, maka pelanggan tidak akan merasa puas.

\section{Faktor-Faktor yang Mempengaruhi Kepuasan}

Kepuasan Pelanggan ditentukan oleh dua variabel kongnitif yakni harapan pada saat sebelum pembelian (prepurchase expectation) dan disconformation yaitu perbedaan antara perbedaan prapembelian dan persepsi dari purnapembelian (post purchase prescription) (Aritonga 2005). Kusnadi juga mengatakan hal-hal yang menentukan puas atau tidak puasya pelanggan adalah mutu produk atau jasa, mutu pelayanan, harga, waktu penyerahan dan keamanan. .

Menurut Moenir (2006:197) untuk menciptakan pelayanan yang baik dan memuaskan ada empat persyaratan pokok antara lain : kesopanan petugas layanan, cara menyampaikan sesuatu saat pelayanan pada konsumen, waktu dan ketepatan penyampaian informasi oleh pelayan, dan keramahan dari seorang pelayan saat melayani. 


\section{Dimensi Kepuasan Konsumen}

Hal yang dapat mempengaruhi kepuasan pelanggan dapat dilihat dari ukuran atau dimensi kepuasan pelanggan menurut Kotler (2011), yaitu:

1. Tetap setia

2. Membeli produk yang ditawarkan

3. Merekomendasi produk

4. Bersedia membayar lebih

5. Memberi masukan

\section{Komponen Kepuasan Konsumen}

Menurut Giese \& Cote ( Jill Griffin : 2005) “ sekalipun banyak definisi kepuasan konsumen, namun secara umum tetap mengarah kepada tiga komponen utama, antara lain respon, fokus, dan waktu respon
a. Respon
b. Fokus
c. Waktu respon

\section{Pengukuran Kepuasan Konsumen}

Pengukuran kepuasan konsumen sangatlah penting untuk menilai kinerja pelayanan yang diberikan kepada masyarakat, ada 4 metode yang dikemukakan oleh Tjipto dan Gregorius candra (2005 : 130) yang dapat dipergunakan untuk mengukur kepuasan pelanggan yaitu:

1. Sistem Keluhan dan Saran

2. Survei kepuasan pelanggan

3. Ghost Shopping (Pelanggan Bayangan)

4. Analisa Pelanggan yang Beralih

\section{Kerangka Berpikir}

Gambar : 2 Kerangka Berpikir

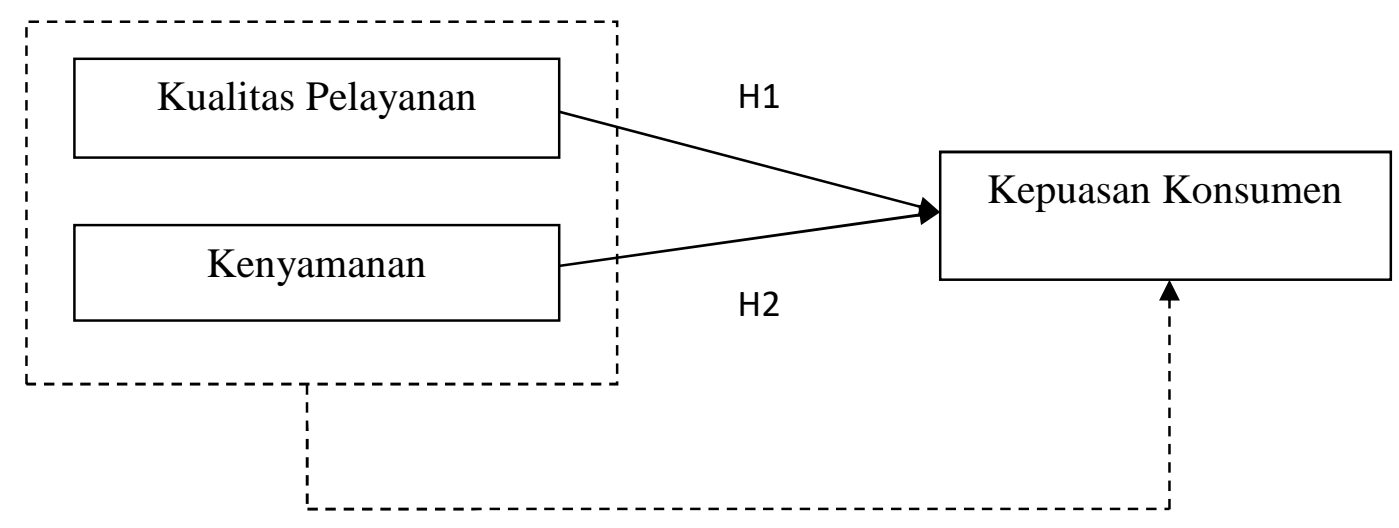


Sumber : Atika Zahra (2017)

Keterangan :

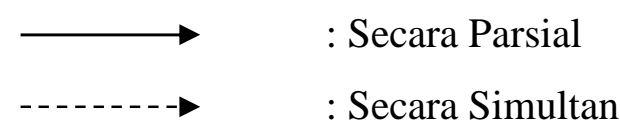

\section{Hipotesis}

H1 : Kualitas pelayanan berpengaruh terdahadap kepuasan konsumen pengguna jasa ojek online Go-jek di Kota Kediri.

H2 : Kenyamanan berpengaruh terdahadap kepuasan konsumen pengguna jasa ojek online Go-jek di Kota Kediri.

H3 : Kualitas pelayanan dan kenyamanan berpengaruh terdahadap kepuasan konsumen pengguna jasa ojek online Go-jek di Kota Kediri.

\section{METODE PENELITIAN}

\section{Populasi}

Seluruh pengguna jasa ojek online Go-jek di Kota Kediri pada tahun 2017 merupakan populasi dalam penelitian ini dan jumlahnya tidak diketahui. Untuk menentukan jumlah sampel kami menggunakan Teknik Snowball Sampling, Menurut Sugiyono (2010:217) Snowball Sampling yaitu “ teknik penentuan jumlah sampel yang semula kecil kemudian terus membesar ibarat bola salju". Kriteria yang akan dijadikan sampel adalah pengguna go-jek minimal 2x selama 6 bukan terakhir pada tahun 2017 .

Teori Roscoe dapat digunakan bila responden dalam penelitian berjumalh 30500 orang responden, sampel harus dikelompokkan dalam kategori, pada analisis multivarite atau regresi berganda. Misal ada 5 variabel dependen dan independen, maka jumlah anggota sampel harus 10 x $5=50$. Berdasarkan saran poin pertama diatas, maka peneliti mengambil sampel sebanyak 100 responden dari pemakai layanan jasa ojek online Go-jek di kota Kediri.

\section{Metode Pengumpulan Data}

Metode pengumpulan data dalam penelitian ini mengguanakan :

1. Metode survei langsung

2. Kuesioner yang dinilai dengan skala likert dengan nilai 1-5

3. Studi Pustaka 


\section{Metode Analisis Data}

Sebelum dilakukan analisis data, terlebih dahulu perlu mengungkap bagaimana mengukur keabsahan (validity) dan keterandalan (reliability) dari instrumen yang digunakan penelitian. Menurut Sugiyono (2012) instrumen yang valid dan relibel merupakan syarat mutlak untuk mendapat hasil penelitian yang valid dan realibel. Tahap analisis data dilakukan sebagai berikut :

\section{Uji Instrumen Penelitian :}

\section{Uji Validitas}

Uji Validitas dilakukan untuk mengetahui kemampuan instrumen dalam mengukur variabel penelitian. Pengujian ini dilakukan untuk mengukur ketepatan dalam setiap item pertanyaan suatu kuesioner yang nantinya akan diberikan kepada responden.

\section{Uji Reabilitas}

Dikatakan reliabel jika dapat memberikan hasil relatif sama pada saat dilakukan pengukuran kembali pada obyek yang berlainan pada waktu yang berbeda atau memberikan hasil yang tetap sesuai dengan kenyataan yang sebenarnya.

\section{Analisis Regresi Linier Berganda}

Analisis ini dimaksudkan untuk mengetahui ada tidaknya pengaruh kualitas pelayanan, kenyamanan terhadap kepuasan pelanggan. Hasil dari analisis regresi adalah berupa koefisien untuk masing-masing variabel independen. Koefisien ini diperoleh dengan cara memprediksi nilai dependen dengan suatu persamaan. Adapun persamaan regresi linier berganda adalah sebagai berikut:

$$
\mathrm{Y}=\mathrm{a}+\mathrm{b} 1 \mathrm{X}_{1}+\mathrm{b} 2 \mathrm{X}_{2}+\mathrm{e}
$$

\section{Analisis Koefisien Determinasi $\left(\mathbf{R}^{2}\right)$}

Menurut Gozali, 2009 "Koefisien determinasi $\left(\mathrm{R}^{2}\right)$ pada intinya mengukur seberapa jauh kemanapun model dalam menerangkan variasi variabel dependennya. Nilai koefisien determinasi $\left(\mathrm{R}^{2}\right)$ yang mendekati satu berarti variabel - variabel independennya menjelaskan hampir semua informasi yang dibutuhkan untuk memprediksi variabel dependen”. 


\section{HASIL PENELITIAN}

\section{Uji Validitas}

Hasil dari uji validitas pada penelitian ini dengan besarnya df dapat dihitung 100-2 = 98, dengan df 98 dan alpha 5\% $(0,05)$ didapat $r$ tabel sebesar 0,1654.

\begin{tabular}{|c|c|c|c|c|}
\hline \multirow{2}{*}{ Variabel } & Item & $\begin{array}{c}\text { Corrected item total } \\
\text { Correlation (r hitung) }\end{array}$ & r tabel & Keterangan \\
\hline \multirow{4}{*}{$\begin{array}{c}\text { Kepuasan } \\
\text { Konsumen (y) }\end{array}$} & $\mathrm{Y}_{1}$ & 0,756 & 0,1654 & Valid \\
\cline { 2 - 5 } & $\mathrm{Y}_{2}$ & 0,734 & 0,1654 & Valid \\
\cline { 2 - 5 } & $\mathrm{Y}_{3}$ & 0,643 & 0,1654 & Valid \\
\cline { 2 - 5 } & $\mathrm{Y}_{4}$ & 0,463 & 0,1654 & Valid \\
\cline { 2 - 5 } & $\mathrm{Y}_{5}$ & 0,593 & 0,1654 & Valid \\
\hline \multirow{4}{*}{$\begin{array}{c}\text { Kualitas } \\
\text { Pelayanan (x1) }\end{array}$} & $\mathrm{X}_{1.1}$ & 0,722 & 0,1654 & Valid \\
\cline { 2 - 5 } & $\mathrm{X}_{1.2}$ & 0,691 & 0,1654 & Valid \\
\cline { 2 - 5 } & $\mathrm{X}_{1.3}$ & 0,808 & 0,1654 & Valid \\
\cline { 2 - 5 } & $\mathrm{X}_{1.4}$ & 0,741 & 0,1654 & Valid \\
\cline { 2 - 5 } Kenyamanan (x2) & $\mathrm{X}_{1.5}$ & 0,812 & 0,1654 & Valid \\
\cline { 2 - 5 } & $\mathrm{X}_{2.1}$ & 0,645 & 0,1654 & Valid \\
\cline { 2 - 5 } & $\mathrm{X}_{2.2}$ & 0,920 & 0,1654 & Valid \\
\hline
\end{tabular}

Dari tabel diatas dapat disimpilkan bahwa semua indikator dari ketiga variabel $\mathrm{Y}, \mathrm{X}_{1}$ dan $\mathrm{X}_{2}$ adalah valid.

\section{Uji Reliabilitas}

Uji reabilitas digunakan untuk mengukur suatu kuesioner yang merupakan indikator dari variabel. Suatu kuesioner dikatakan realibel jika jawaban konsisten dari waktu ke waktu. Suatu kuesioner dinyatakan realibel jika nilai Croanbach's Alpha> 0,06. Adapun hasil pengujian reabilitas yaitu variabel $\mathrm{Y}$ memperoleh nilai 0,748, variabel $\mathrm{X}_{1}$ memperoleh nilai 0,795 dan variabel $\mathrm{X}_{2}$ memperoleh nilai 0,834 dengan hasil tersebut, maka dapat disimpulkan bahwa masing-masing variabel memiliki Cronbach Alpha $\geq 0,7$. Dengan demikian variabel $\mathrm{Y}, \mathrm{X}_{1}$ dan $\mathrm{X}_{2}$ dapat dikatakan realibel.

\section{Analisis Regresi Linier Berganda}

Hasil dari analisis regresi adalah berupa koefisien untuk masing-masing variabel independen. 
Tabel Hasil Regresi Linier Berganda

\section{Coefficients $^{a}$}

\begin{tabular}{|c|c|c|c|c|c|c|}
\hline \multirow{2}{*}{\multicolumn{2}{|c|}{ Model }} & \multicolumn{2}{|c|}{ Unstandardized Coefficients } & \multirow{2}{*}{$\begin{array}{c}\begin{array}{c}\text { Standardized } \\
\text { Coefficients }\end{array} \\
\text { Beta }\end{array}$} & \multirow[b]{2}{*}{$\mathrm{t}$} & \multirow[b]{2}{*}{ Sig. } \\
\hline & & $\mathrm{B}$ & Std. Error & & & \\
\hline \multirow[t]{3}{*}{1} & (Constant) & 9,403 & 1,242 & & 7,570 &, 000 \\
\hline & $\mathrm{x} 1$ & , 177 & ,098 & ,222 & 1,806 & , 074 \\
\hline & $x 2$ & ,504 & , 154 & , 402 & 3,268 &, 001 \\
\hline
\end{tabular}

a. Dependent Variable: $y$

Sumber : Data Output SPSS setelah diolah (2018)

Berdasarkan tabel diatas, maka hasil yang diperoleh dimasukkan dalam persamaan sebagai berikut :

$\mathrm{Y}=9,403+0,177 \mathrm{X}_{1}+0,504 \mathrm{X}_{2}+\mathrm{e}$

Dari tabel persamaan diatas maka koefisien regresi yang didapatkan dapat dijelaskan sebagai berikut:

a. Konstanta a $=9,403$ artinya apabila variabel Kualitas Pelayanan dan Kenyamanan sama dengan nol atau tidak berubah, maka kepuasan konsumen(Y) akan mengalami penurunan 9,403 .

b. Nilai koefisien variabel Kualitas Pelayanan $\left(\mathrm{X}_{1}\right)$ sebesar 0,177. Berarti bahwa setiap kenaikan satu nilai pada variabel kualitas pelayanan $\left(\mathrm{X}_{1}\right)$, maka kepuasan konsumen (Y) akan mengalami peningkatan sebesar 0,177.

c. Nilai koefisien variabel Kenyamanan $\left(\mathrm{X}_{1}\right)$ sebesar 0,504. Berarti bahwa setiap kenaikan satu nilai pada variabel kenyamanan $\left(\mathrm{X}_{2}\right)$, maka kepuasan konsumen $(\mathrm{Y})$ akan mengalami peningkatan sebesar 0,504.

\section{Analisis Koefisien Determinasi $\left(\mathbf{R}^{2}\right)$}

Dari analisis koeisien determinasi $\left(\mathrm{R}^{2}\right)$, diperoleh angka $\mathrm{R}^{2}$ ( $\mathrm{R}$ Square) sebesar 0,343 atau 34.3\%. Demikian menunjukkan bahwa adalah Kualitas pelayanan dan kenyamanan menjelaskan kepuasan konsumen sebesar 34,3\%. Sedangkan sisanya $65,7 \%$ dijelaskan oleh variabel-variabel lain yang tidak diteliti atau dikaji dalam penelitian ini.

\section{Uji Hipotesis}

\section{Uji Parsial (Uji t)}

Berdasarkan hasil uji parsial untuk variabel Kualitas Pelayanan diperoleh $\mathrm{t}$ hitung sebesar 1,806 dengan nilai signifikasi sebesar 0,074>0,05. Maka hal ini menunjukkan bahwa secara parsial H1 yang menyatakan bahwa secara parsial Kualitas Pelayanan berpengaruh terhadap Kepuasan Konsumen ditolak. 
Berdasarkan hasil uji parsial untuk variabel Kenyamanan diperoleh t hitung sebesar 3,268 dengan nilai signifikan 0,001<0,05. Maka hal ini menunjukkan bahwa secara parsial H2 yang menyatakan bahwa secara parsial Kenyamanan berpengaruh terhadap Kepuasan Konsumen diterima.

\section{Uji Simultan (Uji F)}

Dari hasil uji simultan (uji F), dipeoleh hasil variabel Kualitas Pelayanan $\left(\mathrm{X}_{1}\right)$ dan Kenyamanan $\left(\mathrm{X}_{2}\right)$ secara simultan berpengaruh terhadap variabel Kepuasan Konsumen (Y), sehingga pada penelitian ini Ho ditolak Ha diterima.

\section{Pembahasan}

Setelah dilakukannya uji secara stastistik dengan bantuan SPSS, maka dapat dijelaskan ada hubungan secara langsung dan tidak langsung anatara variabel yang diteliti dengan penjelasan sebagai berikut:

\section{Pengaruh Kualitas Pelayanan Terhadap Kepuasan Konsumen}

Untuk variabel kualitas pelayanan memperoleh hasil sig. 0,074 dapat diartikan bahwa variabel ini tidak mempunyai dampak positif terhadap variabel kepuasan konsumen pada penelitian ini.

Berdasarkan hasil uji hipotesis yang telah dilakukan, tidak terdapat pengaruh dari variabel kualitas pelayanan terhadap kepuasan konsumen pengguna jasa ojek online Go-Jek di Kota Kediri. Dari hasil ini dapat disimpulkan bahwa hasil penelitian tidak sejalan dengan pernyataan dari Lupiyoadi dan Hamdani (2009:65) yang mengemukakan bahwa kualitas pelayanan berpengaruh terhadap kepuasan pelanggan, dimana pelayanan yang baik berakibat lebih besar terhadap kepuasan pelanggan. Kualitas pelayanan dapat mempengaruhi kepuasan konsumen karena terjadinya interaksi antara konsumen dan pihak dari perusahaan. Strategi perusahaan harus tepat dalam memenangkan persaingan (Putra, 2014). Namun hasil dari penelitian ini tidak sesuai karena kurangnya pelayanan yang diberikan oleh PT Go-Jek dan ditemui dilapangan dari jawaban responden ratarata bernilai rendah terutama pada indikator bukti fisik yang menyatakan bahwa kecepatan dan kerapian dari pelayanan yang diberikan Go-Jek sangat kurang .

\section{Pengaruh Kenyamanan Terhadap Kepuasan Konsumen}

Dari persamaan regresi diperoleh nilai koefisien pengaruh kenyamanan terhadap kepuasan konsumen 0,504. Berarti variabel kenyamanan berpengaruh signifikan 
terhadap kepuasan konsumen pada pengguna jasa ojek online Go-Jek di Kota Kediri. Hasil tersebut sesuai dengan pernyataan Kolcaba (2003). Apabila terdapat perasaan sejahtera maka kenyaman yang dirasakan konsumen telah terpenuhi sehingga secara otomatis konsumen akan merasa puas.

\section{Pengaruh Kualitas Pelayanan dan Kenyamanan Terhadap Kepuasan Konsumen}

Berdasarkan hasil uji dalam penelitian ini, dapat diartikan bahwa pengaruh yang signifikan dari kualitas pelayanan dan kenyamanan terdapat pengaruh terhadap kepuasan konsumen pengguna jasa ojek online Go-Jek di kota kediri. Hal ini dibuktikan dari nilai f hitung sebesar 25,325 dengan nilai signifikasi $0,000<0,05$.

\section{KESIMPULAN DAN SARAN}

\section{Kesimpulan}

Berdasarkan penelitian dan pembahasan, dapat disimpulkan sebagai berikut:

1. Secara parsial variabel kualitas pelayanan tidak berpengaruh terhadap kepuasan konsumen pengguna jasa ojek online Go-Jek di kota kediri. Hal ini dibuktikan dari nilai t hitung sebesar 1,806 dengan nilai koefisien regresi sebesar 0,177 tetapi tidak signifikan dilihat dari nilai signifikasi yaitu sebesar 0,074>0,05.

2. Secara parsial variabel kenyamanan terdapat pengaruh terhadap kepuasan konsumen pengguna jasa ojek online Go-Jek di kota kediri. Hal ini dibuktikan dari nilai t hitung sebesar 3,268 degan nilai koefisien regresi sebesar 0,504 dan nilai signifikasi $0,001<0,05$.

3. Secara simultan variabel kualitas pelayanan dan variabel kenyamanan terdapat pengaruh terhadap kepuasan konsumen pengguna jasa ojek online Go-Jek di kota kediri. Hal ini dibuktikan dari nilai f hitung sebesar 25,325 dengan nilai signifikasi $0,000<0,05$.

\section{Saran}

Berdasarkan kesimpulan yang diperoleh dalam penelitian ini, maka dilanjutkan saran-saran pelengkap terhadap hasil penelitian sebagai berikut:

1. Berdasarkan hasil penelitian diketahui bahwa pada variabel kualitas pelayanan memiliki nilai yang rendah, oleh karena itu, PT GO-JEK Indonesia disarankan untuk meningkatkan fasilitas pelayanan dengan cara memberikan kemudahan untuk 
memesan layanan Go-Jek dan driver Go-jek sebaiknya menanyakan apa yang dibutuhkan konsumen. Diharapkan ini dapat meningkatkan kualitas pelayanan dan bisa menciptakan kepuasan konsumen.

2. Berdasarkan hasil penelitian variabel kenyamanan berpengaruh signifikan, oleh karena itu, PT GO-JEK Indonesia disarankan untuk selalu mempertahankan dan juga dapat meningkatkan pelayanan yang nyaman dengan mendambah fasilitas seperti memberikan mantel disaat hujan agar konsumen tetap merasa nyaman disemua kondisi. Diharapkan langkah tersebut dapat menambah rasa nyaman yang dirasakan pengguna jasa Go-Jek dan pada akhirnya dapat menciptakan kepuasan konsumen.

3. Penelitian selanjutnya dapat mengembangkan penelitian ini dengan menggunakan metode lain dalam meneliti kualitas pelayanan, kenyamanan, dan kepuasan konsumen, misalnya melalui wawancara yang mendalam terhadap responden. Sehingga informasi yang didapat lebih bervariasi. Selain itu, penelitian selanjutnya dapat juga menguji dengan variabel lain yang dapat mempengaruhi kepuasan pelanggan, seperti: citra merek, kualitas produk, persepsi harga, dll.

\section{DAFTAR PUSTAKA}

Arikunto, Suharsimi. 2008.Prosedur Penelitian. Jakarta: Rineka cipta.

Ai Lili, Januar Efendi. 2016. DeReMa Jurnal Manajemen. Vol. 11 No.2

Ardiana, Lintang.2007. Persepsi Ketidaknyamanan Lingkungan di Kehidupan perkotaan (Suatu Studi Deskriptif pada Warga Kota Bogor). Skripsi. Fakultas Psikologi Universitas Indonesia. Availabel on: http://www.lontar.ui.ac.id/file?file=digital/124448-155.942\%20ARD\%20p\%20\&20\%Persepsi\%20ketidaknyamanan-Literatur.pdf. Diakses: Rabu, 07 Maret 2018

http://www.go-jek.com2017. Diakses: Selasa, 13 Februari 2018.

https://www.slideshare.net/mobile/tyasseptya/definisi-kenyamanan. Diakses: Rabu, 28 Maret 2018.

Gandung Satriyono \& Desi Kristanti. (2018). Pengaruh kepuasan pasien pada kualitas layanan Rawat Inap terhadap niat Discharge Against Medical Advice ( DAMA ) ( Studi di Rumah Sakit Umum Daerah Pare Kabupaten Kediri ). Ekonika, 3(2), 136153. https://doi.org/https://doi.org/10.30737/ekonika.v3i2.190

Putra, Y. P. (2014). Formulasi Strategi Bersaing Pada Universitas Kadiri Dalam Menghadapi Persaingan Antar Perguruan Tinggi Sejenis di Kota Kediri. Universitas Airlangga, Surabaya.

Yunanto, Y. (2017). Pengaruh Kualitias Peayanan Dan Disiplin Kerja Aryawan Biro Administrasi Umum Terhadap Kepuasan Mahasiswa, 15(2), 99-104.

Kotler,Philip \& Kevin L. Keller. 2009. Manajemen pemasaran jilid I edisi keduabelas, 
Terjemahan Bab Sabran. Jakarta: Erlangga.

Kotler dan Amstrong. 2001. Prinsip-prinsip Pemasaran. Jilid 2. Edisi Kedelapan. Jakarta: Erlangga.

Kotler, P. 2008 Manajemen Pemasaran. Jilid 2. Jakarta. Bumu Aksara.

Karwowski, dan Marras. Ed. 2003,Principles and Application in Engineering Saries Occupational Ergonomics Engineering and Administrative Controls. Florida:CRC Press.

Koestanto, Tri Hari. 2014. Pengaruh Kualitas Pelayanan Terhadap Kepuasan Pelanggan Pada Bank Jatim Cabang Klamis Surabaya. Surabaya.

Kharista, Afrinda Dkk. 2015. Pengaruh Kualitas Pelayanan Terhadap Kepuasan Pelanggan (survey pada pelanggan Fedex Express Surabaya). Malang.

Lapiyoadi. Rambat dan A. Hamdan, 2008.Manajemen Pemasaran Jasa Edisi 2. Jakarta: Salemba Empat

Mawardi.Kholid.M. dkk. 2015. Jurnal Administrasi Bisnis (JAB). Vol. 25 No. 2.

Magnolia. 2010. Kenyamanan pelanggan adalah Bagian Penting dari kenyamanan.(online),tersedia:http://forum.vibizportal.com/archive/index.php?t-

15362.html. Diakses: Rabu 28 Maret 2018.

Moenir. 2001. Manajemen Pelayanan Umum Indonesia. Jakarta. Bumi. Aksara

Nurmasari, Selvy. Dkk. 2013. Pengaruh Kualitas Pelayanan Terhadap Kepuasan Pelanggan antara Perusahaan dan Loyalitas pelanggan Survei pada Tamu Pelanggan yang menginap di Hotel Pelangi Malang. Malang.

Parasuraman, A Zeithaml., Valerie, Berry (1985) dlm Tjiptono (2012: 174), A conceptual Model of Service Quality and Its Complication For Future Research. The Jurnal Marketing.

Septanto. Henri. 2016. Ekonomi Kreatif dan Inovatif Berbasis TIK ala Gojek dan Grabbike. BINA ISNSANI ICT JURNAL, Vol. 3, No. 1, Hal 213 - 219.

Sulistiyawati, Arie, Ni Made,\& Seminari. Ketut. 2015. Pengaruh Kualitas Pelayanan TerhadapKepuasan Pelanggan pada Restoran Idrus Ubud Gianyar. Bali.

Sugiyono. 2012.Memahami Penelitian Kualitatif. Bandung: Alfabeta.

Rahayu, Agustina. 2017. Pengaruh Kualitas Produk dan Harga Terhadap Kepuasan Konsumen M3(Studi pada siswa SMKN 2 Nganjuk): Fakultas Ekonomi Universitas Kadiri. Skripsi.

Tjiptono. Fandy. 2007. Strategi Pemasaran. Edisi Pertama. Andi Omset. Yogyakarta.

Tjiptono, F 2008. Pemasaran jasa, Edisi pertama. Cetak Ketiga. Malang. Bayumedia Publising.

Tri, Hari. 2014. Jurnal ilmu \& Riset Manajemen. Vol. 3 No. 10.

Wijayanti .Ayu, Aprilia. 2014. Analisis Pengaruh Kualitas Pelayanan Terhadap Tingkat Kepuasan konsumen pada Apotek Seger Jombang: Fakultas Ekonomi Universitas Kadiri. Skripsi. Kediri.

Yuliati, Ai Lili, \& Panjaitan,F, Januar. 2016. Pengaruh Kualitas Terhadap Kepuasan Pelanggan pada Cabang JNE Bandung. Bandung. 